\title{
PENGARUH KOMBINASI SUHU DAN DEHUMIDIFIKASI UDARA PENGERING TERHADAP AKTIVITAS ANTIOKSIDAN IRISAN BUAH MENGKUDU (Morinda citrifolia)
}

\author{
[The Effect of Combination of Temperature and Drier Air Dehumidification \\ On Antioxidant Activities of Noni Slices]
}

\author{
Ruth Riama Magdalena Marbun*, Sholahuddin dan Tri Rahayuni \\ Fakultas Pertanian, Jurusan Budidaya Pertanian, Universitas Tanjungpura \\ Jl. Prof. Dr. H.Hadari Nawawi Pontianak, Telp/Fax. (0561)740191 \\ *Email: ruthriamamm@gmail.com
}

Diterima 13 Januari 2020 / Disetujui 06 Juli 2020

\begin{abstract}
Fresh noni fruit has nutrients and active components and contains high water content. Noni has a short shelf life caused by high of water content, so it is necessary to reduce the water content of the material by drying. The purpose of this study was to determine the effect of method and drying temperature combination on antioxidant activity of noni slices which include ascorbic acid, total flavonoids, and antioxidant activity. This study was designed using Randomized Block Design (RBD) with combination of 2 treatment factors, namely the drying temperature $(T)$ and the drying method $(M)$ and 3 replications. The drying method uses three methods, namely conventional hot air, dehydrated hot air, and circulated dehydrated hot air, while the drying temperature used was $50^{\circ} \mathrm{C}, 57^{\circ} \mathrm{C}$ and $65^{\circ} \mathrm{C}$. Data analysis for ascorbic acid, total flavonoids, and antioxidant activity using ANOVA test $(a=5 \%)$ and HSD test $(a=5 \%)$, while drying time was analyzed descriptively. The results showed that the highest antioxidant activity with conventional methods at $50{ }^{\circ} \mathrm{C}$ was 34\% with the characteristics of ascorbic acid $52.8 \mathrm{mg} / 100 \mathrm{~g}$ of noni dried fruit, total flavonoids $3.81 \mathrm{mg}$ QE/g of noni dried fruit, and drying time for 18 hours.
\end{abstract}

Keywords: adsorbent, antioxidant, drying, noni, temperature

\section{ABSTRAK}

Buah mengkudu segar kaya akan nutrisi dan komponen aktif serta mengandung kadar air tinggi. Tingginya kadar air mengakibatkan masa simpan yang singkat, sehingga perlu dilakukan pengeringan. Penelitian ini bertujuan untuk mengetahui pengaruh kombinasi metode dan suhu pengeringan terhadap aktivitas antioksidan irisan buah mengkudu yang meliputi asam askorbat, total flavonoid, dan aktivitas antioksidan. Penelitian ini menggunakan Rancangan Acak Kelompok (RAK) desain faktorial yang terdiri dari kombinasi dua faktor perlakuan, yaitu suhu pengeringan $(T)$ dan metode pengeringan ( $M$ ) serta 3 ulangan. Metode pengeringan menggunakan tiga metode, yaitu metode konvensional, metode adsorpsi dan metode sirkulasi, sedangkan suhu pengeringan yaitu $50^{\circ} \mathrm{C}, 57^{\circ} \mathrm{C}$ dan $65^{\circ} \mathrm{C}$. Analisa data untuk asam askorbat, total flavonoid, dan aktivitas antioksidan menggunakan ANOVA ( $a=5 \%)$ dan uji BNJ $(a=5 \%)$, sedangkan lama pengeringan dianalisa secara deskriptif. Hasil penelitian menunjukkan bahwa aktivitas antioksidan tertinggi dengan metode konvensional pada suhu $50^{\circ} \mathrm{C}$ yaitu sebesar $34 \%$ dengan karakteristik asam askobat sebesar $52,8 \mathrm{mg} / 100 \mathrm{~g}$ buah mengkudu kering, total flavonoid sebesar $3,81 \mathrm{mg}$ QE/g buah mengkudu kering, dan lama pengeringan selama 18 jam.

Kata kunci: adsorben, antioksidan, mengkudu, pengeringan, suhu

\section{PENDAHULUAN}

Mengkudu (Morinda citrifolia) merupakan tanaman yang banyak ditemukan di daerah tropis, termasuk Indonesia (Aruna dkk., 2013). Pada umumnya tanaman mengkudu tumbuh secara liar, namun tak jarang pula masyarakat membudidayakan tanaman ini untuk diambil buahnya. Mengkudu banyak digunakan oleh masyarakat sebagai obat tradisional untuk menyembuhkan berbagai penyakit.

Buah mengkudu kaya zat gizi serta fitokimia yang berfungsi sebagai antioksidan. Zin dkk. (2002) menyatakan bahwa bagian buah dan daun mengkudu memiliki kemampuan sebagai antioksidan alami. Aktivitas antioksidan buah mengkudu dipengaruhi kandungan flavonoid dan senyawa fenolik (Rao dan Subramanian, 2009). 
Pemanfaatan komponen antioksidan pada buah mengkudu dapat diaplikasikan menjadi beberapa jenis produk pangan. Di sisi lain, buah mengkudu mengandung kadar air yang tinggi, yaitu sekitar $89,10 \%$ (Jones, 2000). Tingginya kadar air pada buah mengkudu mengakibatkan buah mengkudu memiliki masa simpan yang singkat, sehingga perlu dilakukan proses pengurangan kadar air bahan yang dilakukan dengan pengeringan.

Proses pengeringan dipengaruhi oleh suhu dan lama pengeringan. Suhu yang tinggi dapat mempercepat proses pengambilan kadar air bahan sehingga proses pengeringan berlangsung lebih cepat. Di sisi lain, suhu yang tinggi dapat mempengaruhi senyawa antioksidan yang terkandung pada buah mengkudu, karena senyawa antioksidan sensitif terhadap panas. Pengeringan untuk bahan yang sensitif terhadap panas harus dilakukan dengan suhu rendah.

Salah satu metode pengeringan yaitu dengan aplikasi udara panas yang secara umum diaplikasikan pada oven. Kapasitas pengeringan udara dalam pengering konveksi menggunakan aliran udara panas bergantung pada suhu dan kelembaban udara. Kapasitas pengeringan dapat ditingkatkan dengan meningkatkan suhu, menurunkan kelembaban absolut, maupun kombinasi keduanya. Kelembaban udara dapat diturunkan dengan menggunakan bahan penyerap atau adsorben (Djaeni dkk., 2007).

Pengeringan adsorpsi adalah metode pengeringan dengan menurunkan kadar air udara sebelum dimasukkan dalam ruang pengeringan. Penurunan kadar air udara dilakukan menggunakan bahan penyerap/ adsorben seperti silika gel dan zeolit. Kelembaban udara rendah dapat mempercepat penguapan air dari bahan, menurunkan kebutuhan panas selama proses, serta mempersingkat waktu pengeringan dan dapat diaplikasikan untuk pengeringan suhu rendah (Djaeni dkk., 2012). Metode sirkulasi merupakan modifikasi dari metode adsorpsi. Menurut Djaeni (2008), udara panas yang terbuang pada metode sirkulasi dapat digunakan kembali untuk tahap pengeringan berikutnya. Sementara itu, pada metode pengeringan konvensional tidak dilakukan modifikasi kadar air udara pada alat pengering.

Tujuan dari penelitian ini adalah untuk mengetahui pengaruh metode dan suhu pengeringan terhadap lama pengeringan, kandungan asam askorbat, total flavonoid, serta aktivitas antioksidan irisan buah mengkudu.

\section{BAHAN DAN METODE}

\section{Bahan dan Alat}

Bahan baku adalah buah mengkudu yang hampir matang dengan warna kulit hijau keputih-putihan dan tekstur keras. Bahan-bahan untuk analisis antara lain etanol $96 \%$, akuades, larutan amilum $1 \%$, larutan iodium $0,01 \mathrm{~N}$, metanol, $\mathrm{AlCl}_{3} 10 \%$, kalium asetat $1 \mathrm{M}$, kuersetin, larutan DPPH (1,1-Diphenyl-2 Picrylhyrazil) dan kertas saring Whatman no. 1.

Alat-alat yang digunakan dalam penelitian adalah cabinet dryer yang dilengkapi sistem adsorpsi, timbangan analitik, cawan porselen, blender, ayakan 80 mesh, buret, peralatan gelas, shaker, vacuum pump, spatula, pipet volumetrik, mikro pipet, pipet tetes, vortex, batang pengaduk, spektofotometer UV-Vis, cuvet.

\section{Rancangan Penelitian}

Penelitian ini menggunakan Rancangan Acak Kelompok (RAK) desain faktorial yang terdiri dari kombinasi dua faktor perlakuan, yaitu suhu pengeringan ( $T$ ) dengan 3 taraf suhu $\left(50^{\circ} \mathrm{C}, 57^{\circ} \mathrm{C}\right.$ dan $65^{\circ} \mathrm{C}$ ), dan metode pengeringan $(\mathrm{M})$ yaitu metode konvensional, metode adsorpsi, serta metode sirkulasi. Parameter yang diamati dalam penelitian ini meliputi lama pengeringan, asam asam askorbat, total flavonoid, serta aktivitas antioksidan. 


\section{Pengeringan Buah Mengkudu}

Pengeringan buah mengkudu mengikuti prosedur yang dilakukan oleh Wulan (2015). Buah mengkudu disortasi/ dipilih yang hampir matang dengan warna kulit hijau keputih-putihan dan tekstur keras. Buah dicuci dan diiris dengan ketebalan $\pm 0,5 \mathrm{~cm}$. Sebanyak $\pm 7 \mathrm{~kg}$ irisan buah mengkudu digunakan untuk masing-masing perlakuan pengeringan. Pengeringan dihentikan saat kadar air bahan mencapai $10 \pm 0,5 \%$.

\section{Ekstraksi Buah Mengkudu}

Irisan buah mengkudu yang telah dikeringkan dihancurkan menggunakan blender dan diayak menggunakan ayakan 80 mesh. Sampel serbuk buah mengkudu disimpan dalam wadah yang terhindar dari cahaya dan udara lingkungan untuk dianalisis kadar asam askorbat dengan metode titrasi berdasarkan prosedur kerja Sudarmadji dkk. (1996).

Ekstraksi serbuk buah mengkudu mengacu pada prosedur oleh Pratiwa dkk. (2015) dengan modifikasi. Sampel serbuk dimaserasi menggunakan pelarut etanol $96 \%$ dengan perbandingan serbuk dan pelarut yaitu 1:3 (b/v). Maserasi dilakukan selama 48 jam di atas shaker pada suhu kamar. Larutan kemudian disaring secara vakum dengan kertas saring Whatman no. 1. Filtrat kemudian diuapkan menggunakan rotary evaporator hingga diperoleh ekstrak kental. Selanjutnya dilakukan analisis total flavonoid berdasarkan metode Chang dkk. (2002) dan analisis aktivitas antioksidan dengan metode DPPH menurut Anwar dan Triyasmono (2016).

\section{Analisis Data}

Data lama pengeringan dianalisa secara deskriptif, sedangkan data asam askorbat, total flavonoid, serta aktivitas antioksidan diolah menggunakan analisis sidik ragam (ANOVA) dengan signifikansi 5\%, kemudian dilanjutkan dengan uji Beda Nyata Jujur (BNJ) dengan signifikansi 5\% untuk perlakuan yang berpengaruh nyata.

\section{HASIL DAN PEMBAHASAN}

\section{Lama Pengeringan}

Kadar air buah mengkudu sebelum pengeringan sebesar $86 \%$ (bb). Hasil penelitian menunjukkan bahwa lama pengeringan irisan buah mengkudu hingga mencapai kadar air $10 \%$ berkisar $11-18$ jam (Gambar 1). Proses pengeringan irisan buah mengkudu yang paling cepat terdapat pada perlakuan kombinasi metode sirkulasi dan suhu $65^{\circ} \mathrm{C}$ yaitu selama 11 jam, sedangkan proses pengeringan yang paling lambat terdapat pada perlakuan kombinasi metode konvensional dan suhu $50{ }^{\circ} \mathrm{C}$ yaitu selama 18 jam.

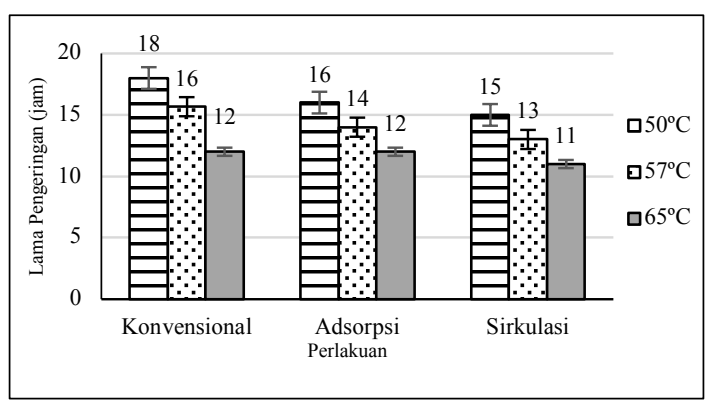

Gambar 1. Rerata Lama Pengeringan Irisan Buah Mengkudu pada Berbagai Perlakuan

Waktu yang dibutuhkan untuk mengeringkan irisan buah mengkudu pada suhu yang lebih tinggi, lebih singkat dibandingan dengan waktu pengeringan pada suhu yang lebih rendah. Hal ini sejalan dengan penelitian Muchtadi dan Sugiyono (2013) yang menjelaskan bahwa semakin tinggi suhu pengeringan akan mempercepat proses penguapan air yang terkandung dalam bahan.

Gambar 1 menunjukkan bahwa pada suhu yang sama, pengeringan dengan penambahan adsorben, yaitu pada metode adsorpsi dan sirkulasi mempersingkat lama pengeringan bahan. Hal ini sejalan dengan penelitian Djaeni (2012) yang menjelaskan bahwa pengeringan dengan menggunakan adsorben dapat menghemat waktu pengeringan sebesar $20-30 \%$.

Pengeringan dengan metode sirkulasi menghasilkan lama pengeringan yang paling 
singkat, meskipun pada prinsipnya hampir sama dengan metode adsorpsi. Hal ini diduga karena pada metode sirkulasi, bahan dikeringkan menggunakan udara panas yang bersirkulasi pada mesin pengering. Penggunaan udara lingkungan hanya di awal pengeringan, lalu dilakukan penurunan kelembaban udara dan suhu dinaikkan. Apabila dibandingkan dengan metode adsorpsi yang pada prinsipnya selalu menggunakan udara baru dari lingkungan, pengeringan dengan metode sirkulasi akan menjadi lebih cepat karena tidak memerlukan waktu lebih untuk proses penyesuaian suhu dan kelembaban.

\section{Asam Askorbat}

Asam askorbat merupakan vitamin dengan struktur kimia paling sederhana, yang terdiri dari 6 atom $C$ dan kedudukannya tidak stabil $\left(\mathrm{C}_{6} \mathrm{H}_{8} \mathrm{O}_{6}\right)$ karena mudah sekali bereaksi dengan $\mathrm{O}_{2}$ di udara menjadi asam dehidroaskorbat (Linder, 1992). Menurut Winarno (2002), vitamin C merupakan vitamin yang paling mudah mengalami kerusakan. Selain mudah larut dalam air, vitamin $\mathrm{C}$ juga mudah teroksidasi oleh panas, alkali, enzim oksidator, dan oksidator lainnya.

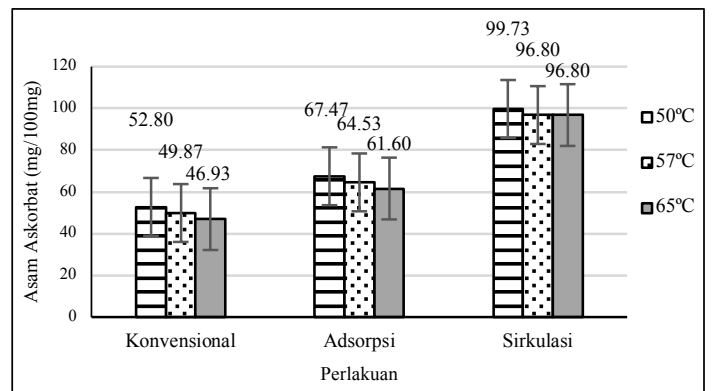

Gambar 2. Rerata Asam Askorbat Irisan Buah Mengkudu pada Berbagai Perlakuan

Analisis kandungan asam askorbat pada penelitian ini bertujuan untuk mengetahui pengaruh metode dan suhu pengeringan terhadap kadar asam askorbat yang terkandung pada irisan buah mengkudu kering. Analisis asam askorbat dilakukan dengan metode titrasi. Nilai rerata kandungan asam askorbat irisan buah mengkudu kering berkisar antara 46,93 hingga 99,73 $\mathrm{mg} / 100 \mathrm{~g}$ sampel buah mengkudu. Rerata kadar asam askorbat irisan buah mengkudu kering ditunjukkan pada Gambar 2.

Hasil analisis berdasarkan uji $F$ (ANOVA) menunjukkan bahwa perlakuan suhu pengeringan tidak berpengaruh nyata dan tidak terdapat interaksi antar faktor perlakuan, sedangkan perlakuan metode pengeringan berpengaruh nyata terhadap kandungan asam askorbat bahan, sehingga dilanjutkan dengan uji Beda Nyata Jujur (BNJ) dengan taraf $5 \%$. Hasil pengujian BNJ $5 \%$ perlakuan metode terhadap kandungan asam askorbat irisan buah mengkudu dapat dilihat pada Tabel 1.

Tabel 1. Uji BNJ Perlakuan Metode terhadap Kandungan Asam Askorbat Irisan Buah Mengkudu

\begin{tabular}{lc}
\hline \multicolumn{1}{c}{ Metode } & Rerata (mg/100g) \\
\hline Konvensional & $49,87^{\mathrm{a}}$ \\
Adsorpsi & $64,53^{\mathrm{b}}$ \\
Sirkulasi & $97,78^{\mathrm{c}}$ \\
\hline \multicolumn{2}{l}{ BNJ 5\% $=9,07$} \\
\hline Keterangan: & angka-angka yang diikuti huruf yang \\
& berbeda berarti berbeda nyata pada uji \\
BNJ taraf 5\%.
\end{tabular}

Pengaruh metode pengeringan terhadap asam askorbat diduga berkaitan dengan lama pengeringan, dimana pengeringan dengan waktu yang lebih singkat menghasilkan irisan buah mengkudu dengan kandungan asam askorbat yang lebih tinggi, dan sebaliknya. Semakin lama sampel terpapar oleh panas, maka kandungan asam askorbat menjadi semakin berkurang. Hal ini sejalan dengan penelitian Sebayang (2016) yang menyatakan bahwa semakin lama waktu pengeringan maka jumlah vitamin $C$ yang teroksidasi akan semakin besar, karena semakin besar pula jumlah panas yang diterima oleh bahan.

Mekanisme oksidasi asam askorbat menghasilkan radikal anion askorbat dan $\mathrm{H}_{2} \mathrm{O}$ yang diikuti pembentukan dehidro asam askorbat dan hidrogen peroksida. Dehidro asam askorbat (asam L-dehidroaskorbat) bersifat sangat labil dan dapat mengalami 
perubahan menjadi 2.3-L-diketogulonat (DKG) yang sudah tidak mempunyai keaktifan asam askorbat lagi. Jika DKG sudah terbentuk maka akan mengurangi bahkan menghilangkan asam askorbat yang ada dalam produk (Andarwulan dan Koswara, 1992).

\section{Total Flavonoid}

Flavonoid merupakan senyawa fenol dan termasuk salah satu metabolit sekunder pada tumbuhan yang berfungsi sebagai antioksidan (Zuraida dkk., 2017). Analisis ini bertujuan untuk mengetahui pengaruh metode dan suhu pengeringan terhadap total senyawa flavonoid irisan buah mengkudu kering. Total flavonoid sampel dihitung dengan memasukkan nilai serapan sampel pada panjang gelombang $415 \mathrm{~nm}$ ke dalam persamaan garis linear $y=a x-b$, yang diperoleh dari kurva kalibrasi kuersetin pada konsentrasi $0 \mathrm{ppm}, 20 \mathrm{ppm}, 40 \mathrm{ppm}, 60$ ppm, 80 ppm, 100 ppm, 120 ppm, dan 140 $\mathrm{ppm}$. Hasil dinyatakan dalam satuan $\mathrm{mg}$ $\mathrm{QE} / \mathrm{g}$ sampel. Rerata total senyawa flavonoid irisan buah mengkudu kering ditunjukkan pada Gambar 3.

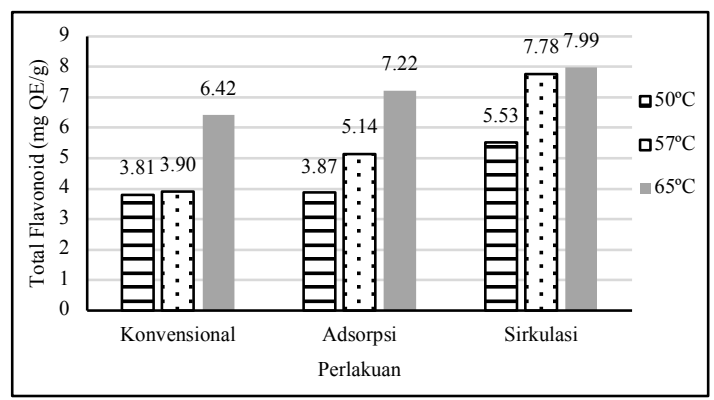

Gambar 3. Rerata Total Flavonoid Irisan Buah Mengkudu pada Berbagai Perlakuan

Nilai rerata total senyawa flavonoid irisan buah mengkudu kering yang terkecil pada kombinasi perlakuan metode konvensional dan suhu $50^{\circ} \mathrm{C}$ yaitu $3,81 \mathrm{mg}$ $\mathrm{QE} / \mathrm{g}$, sedangkan nilai rerata kandungan total flavonoid irisan buah mengkudu kering yang tertinggi terdapat pada kombinasi perlakuan metode sirkulasi dan suhu $65^{\circ} \mathrm{C}$ yaitu 7,99 $\mathrm{mg} \mathrm{QE} / \mathrm{g}$.
Perlakuan suhu dan metode pengeringan berpengaruh nyata serta terdapat interaksi antar faktor perlakuan, sehingga dilanjutkan dengan uji BNJ (Beda Nyata Jujur). Hasil pengujian BNJ 5\% perlakuan suhu pengeringan terhadap total flavonoid irisan buah mengkudu kering terdapat pada Tabel 2 .

Tabel 2. Uji BNJ Perlakuan Suhu Pengeringan terhadap Total Flavonoid Irisan Buah Mengkudu

\begin{tabular}{cc}
\hline Suhu & Rerata (mg QE/g) \\
\hline $50^{\circ} \mathrm{C}$ & $4,40^{\mathrm{a}}$ \\
$57^{\circ} \mathrm{C}$ & $5,61^{\mathrm{b}}$ \\
$65^{\circ} \mathrm{C}$ & $7,21^{\mathrm{c}}$ \\
\hline
\end{tabular}

BNJ 5\% = 1,0714

Keterangan: angka-angka yang diikuti huruf yang berbeda berarti berbeda nyata pada uji BNJ taraf $5 \%$.

Hasil uji BNJ 5\% (Tabel 2) menunjukkan bahwa perlakuan suhu pengeringan berbeda nyata. Pengeringan buah mengkudu pada suhu yang lebih tinggi menunjukkan hasil total flavonoid yang lebih tinggi. Hal tersebut sejalan dengan penelitian Azeez dkk. (2017) pada pengeringan irisan tomat yang menyatakan bahwa terdapat kecenderungan peningkatan total flavonoid dengan meningkatnya suhu pengeringan serta terjadinya penurunan total flavonoid seiring dengan semakin lamanya waktu pengeringan. Hal tersebut disebabkan karena pada suhu yang lebih tinggi lama pengeringan akan semakin singkat, sehingga kontak antara sampel dengan udara panas dapat diminimalisir serta proses degradasi senyawa flavonoid oleh panas tidak berlangsung lama. Sementara itu, Buchner dkk. (2006) menjelaskan bahwa degradasi senyawa flavonoid tidak hanya dipengaruhi oleh suhu dan lama pengeringan. Degradasi flavonoid juga bergantung pada parameter lain seperti struktur bahan, fitokimia, $\mathrm{pH}$, serta keberadaan oksigen. Hasil pengujian BNJ $5 \%$ perlakuan metode pengeringan terhadap total flavonoid irisan buah mengkudu kering terdapat pada Tabel 3. 


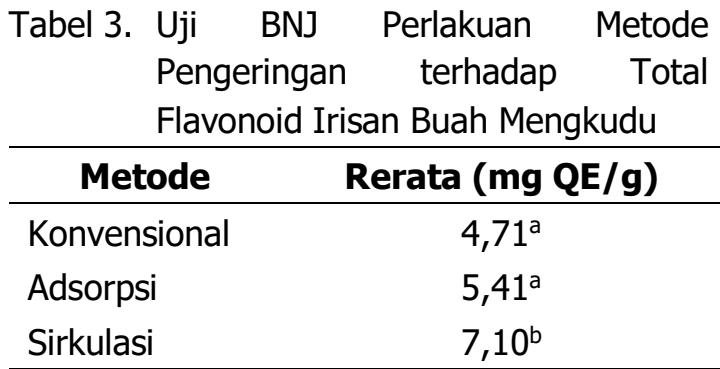

BNJ 5\% $=1,0714$
Keterangan: angka-angka yang diikuti huruf yang berbeda berarti berbeda nyata pada uji BNJ taraf $5 \%$.

Hasil uji BNJ 5\% menunjukkan bahwa perlakuan metode pengeringan berbeda nyata. Semakin singkat waktu pengeringan menghasilkan total flavonoid yang semakin tinggi. Hal ini sejalan dengan penelitian Azeez (2017) pada sampel tomat yang menunjukkan bahwa suhu yang lebih tinggi tidak menurunkan aktivitas antioksidan, apabila dilakukan dalam waktu yang singkat. Menurut Zainol dkk. (2009), flavonoid dan senyawa antioksidan akan mengalami penurunan akibat pengaruh variasi suhu pada saat proses pengeringan karena senyawa tersebut bersifat sensitif terhadap cahaya dan panas. Degradasi flavonoid terjadi karena adanya pemutusan rantai molekul dan terjadinya reaksi oksidasi yang menyebabkan oksidasi gugus hidroksil dan akan membentuk senyawa lain yang mudah menguap dengan cepat. Pengeringan pada metode sirkulasi menghasilkan lama pengeringan yang paling singkat, sehingga dapat meminimalisir kerusakan senyawa flavonoid mengkudu apabila dibandingkan dengan metode konvensional dan metode adsorpsi pada suhu yang sama.

Hasil pengujian BNJ 5\% interaksi metode dan suhu pengeringan terhadap total flavonoid irisan buah mengkudu kering (Tabel 4) menunjukkan bahwa pengaruh interaksi antara metode dan suhu pengeringan berbeda nyata. Diduga, hal ini terjadi karena perbedaan suhu dan metode pengeringan yang menghasilkan lama pengeringan yang berbeda-beda, sehingga mempengaruhi total flavonoid bahan.
Tabel 4. Uji BNJ Interaksi Metode dan Suhu Pengeringan terhadap Total Flavonoid Irisan Buah Mengkudu

\begin{tabular}{|c|c|}
\hline Perlakuan & Rerata (mg QE/g) \\
\hline $\mathrm{k}_{50}$ & $3,807^{a}$ \\
\hline$k_{57}$ & $3,903^{a b c}$ \\
\hline $\mathrm{k}_{65}$ & $6,419^{\text {ef }}$ \\
\hline $\mathrm{a}_{50}$ & $3,870^{a b}$ \\
\hline a57 & $5,139^{d}$ \\
\hline a65 & $7,216^{\mathrm{fg}}$ \\
\hline $\mathrm{S}_{50}$ & $5,530^{\text {de }}$ \\
\hline S57 & $7,778^{g h}$ \\
\hline$S_{65}$ & $7,993^{\mathrm{ghi}}$ \\
\hline
\end{tabular}

\section{Aktivitas Antioksidan}

Aktivitas antioksidan ditentukan oleh besarnya hambatan serapan radikal bebas melalui perhitungan persentase inhibisi serapan radikal DPPH (Santoni dkk., 2013). Analisis aktivitas antioksidan pada penelitian ini bertujuan untuk mengetahui pengaruh metode dan suhu pengeringan terhadap aktivitas antioksidan irisan buah mengkudu kering. Rerata aktivitas antioksidan irisan buah mengkudu kering ditunjukkan pada Gambar 4.

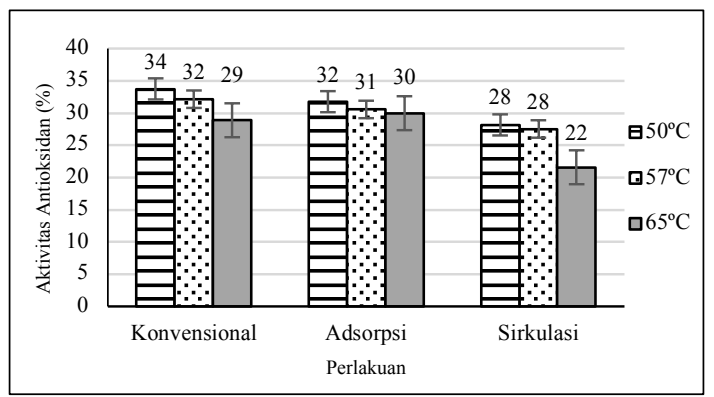

Gambar 4. Rerata Aktivitas Antioksidan Irisan Buah Mengkudu pada Berbagai Perlakuan

Nilai rerata aktivitas antioksidan irisan buah mengkudu kering berkisar antara $22 \%$ hingga 34\%. Hasil analisis berdasarkan uji $F$ (ANOVA) menunjukkan bahwa perlakuan metode dan suhu pengeringan tidak berpengaruh nyata dan tidak terdapat interaksi antar faktor perlakuan, sehingga tidak dilanjutkan dengan uji BNJ. 
Nilai rerata aktivitas antioksidan buah mengkudu kering cenderung menurun seiring dengan semakin tingginya suhu yang diberikan. Sejalan dengan penelitian Syafrida dkk. (2018) yang menyatakan bahwa aktivitas antioksidan sampel cenderung menurun seiring dengan semakin tingginya suhu pengeringan. Reblova (2012) juga menyatakan bahwa terjadi penurunan aktivitas antioksidan seiring dengan meningkatnya suhu pemanasan. Penurunan aktivitas antioksidan akibat peningkatan suhu disebabkan oleh penurunan kemampuan antioksidan untuk bereaksi dengan radikal bebas pada suhu yang lebih tinggi. Antioksidan tidak terurai dengan cepat pada suhu tinggi, namun secara perlahan (dalam kaitannya dengan oksidasi asam lemak).

\section{KESIMPULAN}

Metode pengeringan berpengaruh nyata terhadap asam askorbat, suhu pengeringan berpengaruh nyata terhadap total flavonoid, namun metode dan suhu pengeringan tidak berpengaruh nyata terhadap aktivitas antioksidan mengkudu. Lama pengeringan yang paling singkat yaitu 11 jam dengan metode sirkulasi pada suhu $65^{\circ} \mathrm{C}$, kandungan asam askorbat tertinggi dengan metode sirkulasi pada suhu $57^{\circ} \mathrm{C}$ sebesar 99,73 $\mathrm{mg} / 100 \mathrm{~g}$, kandungan total flavonoid tertinggi pada kombinasi metode sirkulasi dan suhu 65 ${ }^{\circ} \mathrm{C}$ yaitu $7,99 \mathrm{mg} \mathrm{QE} / \mathrm{g}$ dan aktivitas antioksidan tertinggi terdapat pada kombinasi metode konvensional dan suhu $50^{\circ} \mathrm{C}$ yaitu sebesar $34 \%$.

\section{DAFTAR PUSTAKA}

Andarwulan, N dan Koswara, S. 1992. Kimia Vitamin. Jakarta: Rajawali Pers.

Anwar, K. dan Triyasmono, L. 2016. Kandungan Total Fenolik, Total Flavonoid, dan Aktivitas Antioksidan Ekstrak Etanol Buah Mengkudu (Morinda citrifolia L.). Jurnal Pharmascience 3(1): 83-92.

Aruna, M. S., Rama, R. N., Deepthi, B., Lakshmi P. J., dan Surya P. M. 2013.
Ashyuka: A Hub of Medicinal Values. International Journal of Biological \& Pharmaceutical Research 4(12): 1043-1049.

Azeez, L., Segun, A. A., Abdulrasaq, O. O., Rasheed, O. A., dan Kazeem, O. T. 2017. Bioactive Compounds' Contents, Drying Kinetics and Mathematical Modelling of Tomato Slices Influenced by Drying Temperatures and Time. Journal of the Saudi Society of Agricultural Sciences 18(2): 120-126.

Buchner, N., Krumbein, A., Rhon, S. dan Kroh, L. W. 2006. Effect of Thermal Processing on The Flavonols Rutin and Quercetin. Rapid Communications in Mass Spectrometry 20(21): 3229-3235.

Chang, C., Yang, M., Wen, H., dan Chern, J. 2002. Estimation of Total Flavonoid Content in Propolis by Two Complementary Colorimetric Methods. Journal of Food and Drug Analysis 10(3): 178-182.

Djaeni, M. 2008. PhD Thesis Summary: Energy Efficient Multistage Zeolite Drying for Heat Sensitive Products. Drying Technology 27(5): 721-722.

. 2012. Peningkatan Kecepatan Proses Pengeringan Karaginan Menggunakan Pengering Adsorpsi dengan Zeolit. TEKNIK 33(1): 8-12.

Djaeni, M., Bartels, P., Sanders, J., Straten, G. Van, dan Boxtel, A. J. B. Van. 2007. Process Integration for Food Drying with Air Dehumidified by Zeolites. Drying Technology 25(1): 225-239.

Jones, W. 2000. Noni Blessing Holdings. Food Quality Analysis, Oregon.

Linder, M.C. 1992. Biokimia Nutrisi dan Metabolisme dengan Pemakaian Secara Klinis. Jakarta: UI Press.

Muchtadi, T.R dan Sugiyono. 2013. Prinsip Proses dan Teknologi Pangan. Bandung: Alfabeta.

Pratiwa, C., Farah, D., dan Wadina. 2015. Bioaktivitas Ekstrak Etanol Buah Mengkudu (Morinda citrifolia L.) terhadap Rayap Tanah (Coptotermes 
Versi Online:

http://www.profood.unram.ac.id/index.php/profood e-ISSN: 2443-3446

curvignathus Holmgren). Jurnal Hutan Lestari 3(2): 227- 233.

Rao, U.S.M. dan Subramanian, S. 2009. Biochemical Evaluation of Antihyperglycemic and Antioxidative Effects of Morinda citrifolia Fruit Extract Studied in StreptozotocinInduced Diabetic Rats. Medicinal Chemistry Research 18(6): 433-446.

Reblova, Z. 2012. Effect of Temperature on the Antioxidant Activity of Phenolic Acids. Czech Journal Food Science 30(2): 171-177.

Santoni, A., Darwis, D., dan Syahri, S. 2013. Isolasi Antosianin dari Buah Pucuk Merah (syzygium campanulatum korth.) serta Pengujian Antioksidan dan Aplikasi sebagai Pewarna Alami. Dalam: Prosiding Semirata FMIPA Universitas Lampung 1(1): 1-10.

Sebayang, N. S. 2016. Kadar Air dan Vitamin C pada Proses Pembuatan Tepung Cabai (Capsium annuum L). Jurnal Biotik 4(2): 100-110.

Sudarmadji, S., Haryono, B., dan Suhandi. 1996. Prosedur Analisis Bahan Pangan. Jakarta: Gramedia.

Syafrida, M., Sri, D., dan Munifatul, I. 2018. Pengaruh Suhu Pengeringan Terhadap Kadar Air, Kadar Flavonoid dan Aktivitas Antioksidan Daun dan Umbi Rumput Teki (Cyperus rotundus L.). Bioma 20(1): 44-50.

Winarno, F.G. 2002. Kimia Pangan dan Gizi. Jakarta: Gramedia.

Wulan, M. S. 2015. Kajian Kinerja Pengering Surya untuk Pengeringan Irisan Mengkudu (Morinda citrifolia). Skripsi. Banda Aceh: Program Studi Teknik Pertanian. Universitas Syiah Kuala.

Zainol, M., Abdul-Hamid, A., Abu, B. F., dan Pak, D. S., 2009. Effect of Different Drying Methods On The Degradation Of Selected Flavonoids in Centella Asiatic. International Food Reasearch Journal 16(4): 531-537.

Zin, Z. M., Hamid, A. A., dan Osman, A. 2002. Antioxidative Activity of Extracts from Mengkudu (Morinda citrifolia L.) Root, Fruit and Leaf.
Food Chemistry 78(2): 227-231.

Zuraida, Sulistiyani, Sajuthi, D., dan Suparto, I. H. 2017. Fenol, Flavonoid, dan Aktivitas Antioksidan pada Ekstrak Kulit Batang Pulai (Alstonia scholaris R.Br). Jurnal Penelitian Hasil Hutan 35(3): 211-219. 